\title{
SELECTED MACROECONOMIC VARIABLES AND THEIR IMPACT ON THE FINANCIAL PERFORMANCE OF THE MANUFACTURING SECTOR IN KENYA
}

\author{
MARGARET NYARUIRU MUGURE \\ Assistant lecturer chuka university, Kenya \\ DOI: 10.46609/IJSSER.2021.v06i06.023 URL: https://doi.org/10.46609/IJSSER.2021.v06i06.023
}

\begin{abstract}
Manufacturing sector plays an important role in any economy through its contribution to GDP, foreign exchange and employment creation. However, the growth rate of the sector in Kenya is still slow due to various challenges that it faces. The government of Kenya has made efforts to promote production in the sector by investing in heavy machines that are used in production, reduction of corporate tax to encourage more investment, creation of industrial parks among other initiatives. Despite the government effort the growth of the sector has been stagnating. Therefore, there was need to investigate the factors that have led to the slow and stagnant growth rate of the sector. The purpose of this study was to investigate how the impact of selected macroeconomic variables on the financial performance of the manufacturing sector. Particularly the study sought to determine the impact of interest rate, inflation rate and GDP on the financial performance of the manufacturing sector. The study adopted causal research design which helped in investigating the effects of each of these variables on the financial performance of the sector. The target population was all manufacturing industries that are listed in the Nairobi Stock Exchange under manufacturing and allied. Secondary data was obtained from World Bank. Purposive sampling technique was used to select a sample of 36 years from 1980 to 2016. The data was analyzed using SPSS version 20, Eviews, Pc Give ox metrics and STATA softwares to present inferential statistics. The analysis involved descriptive statistics, unit root test, correlation, granger causality and vector error correction model. The test statistics used were tstatistics and f-statistics. The analysis was carried out and interpreted at 5\% significance level. The study found out that there was a significant relationship between interest rate, inflation rate, GDP and the financial performance of the manufacturing sector because the p-value was $0.000<$ 0.05 for all the variables. $\mathrm{R}^{2}$ indicated that $54.87 \%$ of the variation in the financial performance of the sector was caused by interest rate, inflation rate and GDP fluctuation. The study recommended that the Central Bank of Kenya should formulate policies to stabilize macroeconomic variables. The results of this study will be useful in policy making which will
\end{abstract}




\section{International Journal of Social Science and Economic Research}

ISSN: $2455-8834$

Volume:06, Issue:06 "June 2021"

improve the financial performance of the sector and accelerate economic growth and development.

\section{Introduction}

This chapter gives the overall introduction of the research project. It has detailed information on the background of the study, statement of the problem, general and specific objectives of the study, research hypothesis, significance, limitations and scope of the study.

\subsection{Background to the Study}

The manufacturing sector traditionally plays an important role in the development of world economies, both developed and developing. However, in developing countries Kenya included, the manufacturing sector continues to perform poorly leading to de-industrialization or nonindustrialization of these countries (Amirapu and Subramanian,2015). Most developing countries are vigorously trying to come up with policies and initiatives to improve the performance of their manufacturing sector.in Kenya, manufacturing plays an important role as can be seen through the Vision 2030 and the big four agenda. These two policies seek to promote the performance of the sector so as to maintain high rates of economic growth, boost employment opportunities especially for semiskilled labour and build the country's competitiveness through exports (Kenya Association of Manufacturers report, 2018).To achieve these, the government has undertaken various measures to promote growth in the sector such as electrification programs, development of key infrastructure, creation of export processing zones, creation of industrial parks among others. Despite all these, the performance of the sector is still low. According to the World Bank group's economic analysis of Kenya, in 2015 the rate of growth for the manufacturing sector was $6 \%$ and $6.6 \%$ in 2016. This is way below the growth rates projected by the Vision 2030 medium term plan.

The performance of the manufacturing sector is affected by many factors ranging from social, political and economic factors. Macroeconomic variables are indicators of the current trends in the economy. Like all experts, the government, in order to do a good job of macro-managing the economy, must study, analyze, and understand the major variables that determine the current behavior of the macro-economy. There are many macroeconomic variables in economics but this study aimed at studying those variables that seem to have major significant effects on the performance of the manufacturing sector.

Lending interest rates are the cost of borrowing money to add onto fixed capital or to start up a new investment. When banks offer high interest rates it discourages businesspeople from getting loans to add to the capital their businesses and buy equipment. High interest rates can stifle the general level of production in the economy. When banks offer low interest rates, the access to 


\section{International Journal of Social Science and Economic Research}

ISSN: $2455-8834$

Volume:06, Issue:06 "June 2021"

capital for new enterprises is increased and businesses can be started or expanded, and there is generally more money flowing in the economy, which means that the level of production in the economy is increased. Lending interest rates also discourages or encourages both foreign and domestic investments in the manufacturing sector, low rates encourage investment in the sector while high interest rates discourage investment. The Kenya association of manufactures 2018 report cites high cost of financing as on of the major causes of poor performance of the manufacturing sector. The lending interest rates in Kenya have been on an upward trend and therefore there's need to investigate how this has affected the manufacturing sector.

Inflation refers to the persistent increase in the prices of goods and services over a period of time. Inflation has a negative impact on the productivity of the manufacturing sector. The study done by Mohammed (2013) shows that there is a negative significant link between inflation and the manufacturing sector productivity. The findings of the study suggest that inflation has led to a decrease in the manufacturing sector productivity. Inflation affects the aggregate demand, cost of production and levels of investment. During inflation period there is a devaluation of home currency which causes investors to lose confidence in the domestic currency hence preferring to hold foreign currency, these results in low levels of investment in various sectors like manufacturing due to low value of the currency. Inflation also increases the cost of production in the manufacturing sector resulting to low level of productivity in the sector. Apart from inflation and interest rate the GDP also has a great influence on the productivity of the manufacturing sector.

Gross Domestic Product is the monetary value of all finished goods and services produced within a country's borders in a specific period of time usually one year. When the GDP growth is high, firms hire more workers and can afford to pay higher salaries and wages. Due to increase in the number of workers in the manufacturing industries the level of production is also high. Manufacturing industries also have the confidence to invest more when GDP growth is and the investment lays the foundation for economic growth in the future. When GDP growth is low the economy goes into recession and workers may be retrenched and or paid lower wages and firms are reluctant to invest. High GDP levels also enable the government to spend on developing infrastructure needed for industrialization. Hence there is a direct relationship between GDP and the performance of the manufacturing sector.

There has been no research conducted to analyze the effects of macroeconomic variables on the performance of the manufacturing sector in Kenya. Most of the studies conducted on the manufacturing sector analyzed the financial performance of the sector as well as its contribution to GDP of different countries. This study therefore fills this knowledge gap and aims at triggering more research in this area. 
International Journal of Social Science and Economic Research

ISSN: 2455-8834

Volume:06, Issue:06 "June 2021"

\subsection{Statement of the Problem}

Kenya is predominantly an agricultural country with an economy based on production and export of primary agricultural products. The dependence on this primary agricultural products whose export prices are unpredictable, has led to unfavorable terms of trade and unstable balance of payment position. One strategy to reduce this dependence is industrialization. The Kenyan government is shifting its attention to the manufacturing sector due to its importance in national output, exports and job creation. This renewed interest in the sector is evident in the big four agenda which seeks to increase the GDP contribution of the sector to $15 \%$ by 2022.currently, the sector accounts for $14 \%$ of Kenya's Gross Domestic Product despite the fact that Kenya is the most industrially developed country in East Africa. Despite several initiatives being implemented to revamp the sector, its performance has stagnated and decreased. The growth rate in the sector was $3.6 \%$ in 2016 and $4.1 \%$ in 2015 . The slow growth rate may be due to various problems that the sector is facing. Several studies like the study done by Anzeste Were (2016) and Odhiambo, (1991) on the major determinants of the financial performance of the manufacturing sector and the problems facing the sector, have focused mostly on how lack of finance, high energy cost and lack of availability of key information on demand and supply have affected the sector, but they have not looked at how macroeconomic variables have affected the financial performance of the sector. This study therefore aims at filling this gap by studying how macroeconomic variables have affected the financial performance of the manufacturing sector.

\subsection{General Objective}

The general objective of the study is to determine the effect of macroeconomic variables on the financial performance of the manufacturing sector.

\subsubsection{Specific Objectives}

This study was guided by the following specific objectives:

I. To determine the impact of inflation rate on the financial performance of the manufacturing sector.

II. To evaluate the effect of real Gross Domestic Product on the financial performance of the manufacturing sector.

III. To investigate the effect of lending interest rate on the performance of the manufacturing sector.

\subsection{Hypotheses}




\section{International Journal of Social Science and Economic Research}

ISSN: $2455-8834$

Volume:06, Issue:06 "June 2021"

In order to validate the relationship between inflation rate, interest rate and Gross Domestic Product and the financial performance of the manufacturing sector in this study, the following alternative hypotheses are specified:

H01: Inflation rate has no significant effect on the financial performance of manufacturing industries.

H02: Interest rate volatility has no significant effect on the financial performance of manufacturing industries.

H03: There is no relationship between real Gross Domestic Product and financial performance of manufacturing industries.

\subsection{Significance of the Study}

The findings of this study will be important to the policy makers, industry managers and the government. The study will be useful to the government of Kenya in terms of formulating macroeconomic policies so as to control macroeconomic variables. It will help the government to control inflation rate, interest rate and ensure growth of Gross Domestic Product with a view of achieving macroeconomic stability so as to assist manufacturing industries, other companies and firms operating in Kenya. The study will also be useful to the future researchers in terms of reference materials as they design other related studies. It will add knowledge to the existing literature on the impact of macroeconomic variables on the financial performance of the manufacturing sector.

\subsection{Scope of the Study}

The study examines the effect of inflation rate, interest rate and Gross Domestic Product on the financial performance of the manufacturing industries. The study is based in Kenya because the Kenyan manufacturing sector has been experiencing a slow growth rate due to various challenges, the sector also contributes to economic growth. The study employed yearly secondary data on inflation rate, interest rate GDP and value added of manufacturing industries that are listed in the Nairobi Stock Exchange (NSE).The data is obtained from World Bank. The data to be analyzed ranges from 1980 to 2016 . The study uses a 36 years range of data so as to obtain a clear information on the impact of interest rate, inflation rate GDP on the overall performance of the manufacturing sector.

\subsection{Limitations of the Study}

The limitations of this study include data constraint, inadequate research materials, inadequate time and its practicality. There is also the problem of generalization of the outcome of the study 
to all manufacturing industries in Kenya in terms of how inflation, interest rate and gross domestic product affect their financial performance.

\subsection{Assumptions of the Study}

The study assumed that the population was a representative of the whole population (other manufacturing firms and that all manufacturing companies are affected by the same factors as the way the NSE listed manufacturing firms are affected. Thus NSE listed firms represent true and fair picture of all manufacturing companies in Kenya. The study also assumed that the data obtained from World Bank is authentic and free from errors therefore it can be used to derive conclusions about the impact of inflation rate, interest rate, GDP and the financial performance of manufacturing industries in Kenya.

\subsection{Definition of Terms}

Manufacturing: This refers to the production of merchandise for use or sale, using labor and machines, tools, chemical and biological process formulation.

Manufacturing industries: This refers to the branch of manufacture and trade based on the fabrication, processing or preparation of products from row materials and Commodities.

Gross Domestic Product: This is the monetary value of all the finished goods and services produced within a country's borders in a specific time period.

Interest rate: This refers to the percent of principal charged by the lender for use of its money. The principal amount is the amount of money lent.

Inflation: This refers to the rising price of goods and services over time.

Consumer Price Index: This refers to a measure of price changes in consumer goods and Services. The CPI measures price changes from the perspective of the purchaser.

Value added: This is net output of a sector after adding up all output and subtracting intermediate inputs

\section{LITERATURE REVIEW}

\subsection{Introduction}

This chapter focuses on the literature review of the study variables, it reviews the general overview on the manufacturing sector, inflation rate, interest rate and Gross Domestic Product. 
International Journal of Social Science and Economic Research

ISSN: 2455-8834

Volume:06, Issue:06 "June 2021"

It also focuses on empirical literature review, theoretical review conceptual framework and ends with the operationalization of the variables of the study.

\subsection{Overview of the Manufacturing Sector}

The manufacturing sector is one of the most important sectors in the economy of Kenya. It contributes $11.3 \%$ of Kenya's GDP and it comprise of about 3700 manufacturing units. The sector is divided into several broad sub-sectors. The output from the manufacturing sector was valued at 1,097,082 million Kenyan shillings in 2014 up from 1,042,181 million in 2013 (KNBS). The sector has benefited Kenya in various ways that has seen the country's economy grow.

The sector employed over 280,300 people directly in 2013 and 271,000 people in 2012.The informal sector contributes further employment of 1.6 million people. Manufacturing offers multiplier effects through economy wide linkage, for example, more than $25 \%$ of output in Kenya's transport sector is used as an input to other domestic sectors, including manufacturing. It also makes a huge contribution to the tax revenue in terms of income tax recipients from employees, social security contributions and corporation tax levied on profits.

Goods produced at the manufacturing sector are of great benefit to the local consumers since the goods are of high quality, affordable and easily available. Buying locally made products is a source of great pride to Kenyans since it eases reliance on imported goods. Imported goods are not up to standard and can sometimes be counterfeited.

About two thirds of the goods produced by the manufacturing sector in Kenya are consumed locally while the remaining third exported. Overall, exports in 2012 increased by $12.3 \%$ to reach 9.4 billion dollars from 8.4 billion. The African market is the largest destination of Kenya's exports taking up $4.8 \%$ while $26 \%$ of our goods go to the East African community. The European Union is Kenya's second main trading partners and accounts for $24 \%$ of Kenyan exports of which $78 \%$ go to the United Kingdom.

Kenya has attracted both local and foreign investors through Foreign Direct Investment and joint ventures. The manufacturing sector provides domestic firms and workers with exposure to foreign technology and knowledge. This comes in through exporting international buyers or competing with foreign firms in regional and global markets.

\subsection{Empirical Literature Review}

This section entails studies done by other people in Kenya and outside Kenya.Several studies indicate significant relationships exist between inflation, interest rate, GDP and the financial performance of manufacturing industries and other firms in terms of profitability. 
International Journal of Social Science and Economic Research

ISSN: 2455-8834

Volume:06, Issue:06 "June 2021"

\subsubsection{Interest rate and Manufacturing sector}

The relationship of interest rate with the financial performance of the manufacturing sector has been examined by many researchers both in Kenya and outside Kenya.

Torlogh (2013) examined the impact of high bank lending rates on manufacturing output in Nigeria. Data were sourced through the use of questionnaires. He found out that inadequate bank funding impairs the capacity of the manufacturing industries to produce, as banks are reluctant to provide a long term finance required for manufacturing operations. He explains that when banks eventually lend to the sectors, the rates are so high to support manufacturing activity.

Adebiyi and Obasa (2014) examined the impact of interest rate policy on the financing of Nigerian manufacturing sub sector using annual data for the period 1970 to 2002. They found out that interest rates exerts a negative impact on the growth of the subsectors in Nigeria.

Okoye (2006) examined the effect of interest rate on productive activities in Ghana. Using data on selected manufacturing industries, the study shows evidence of positive effect of interest rate on savings but a negative effect on manufacturing output.

Menike (2006) investigated the effect of interest rate fluctuation on stock prices in emerging Sri Lankan stock market using monthly data. The results indicated that most of the companies reported a higher significant coefficient of determination which justifies higher explanatory power of interest rate fluctuation in explaining stock prices. Consistent with similar results of the developed as well as emerging market studies, inflation rate and exchange rate react mainly negatively to stock prices in the COLOMBO Stock Exchange (CSE). The negative effect of Treasury bill rate implied that whenever the interest rate on treasury securities rises investors tend to switch out of stock causing stock prices to fall. The study concluded that since interest rates have a negative effect on stock exchange, they also have a negative impact on the financial performance of firms.

Osoro and Ogeto (2014) investigated the effect of macroeconomic fluctuations on the financial performance of listed manufacturing firms in Kenya. The study found is evidence that foreign exchange, interest rate and inflation rate have significant effects on the performance of the firms in the construction and manufacturing sectors. The effect of macroeconomic factors on the performance of the agricultural sector was however insignificant at $95 \%$ confidence level the effects of macroeconomic factors were inconclusive and thus required further research. The study recommended that the government to come up with strategies and policies to protect the construction, manufacturing and agricultural sectors due to their immense contribution to the economy of the country by formulating policies aimed at controlling the effects of rapid fluctuations of the macro economic factors and their effects on the various sectors. 


\section{International Journal of Social Science and Economic Research}

ISSN: $2455-8834$

Volume:06, Issue:06 "June 2021"

Vaz, Arrives and Brooks (2006) in their study examined the effect of publicly announced changes in official interest rates on the stock returns of the major banks in Australia during the period from 1990 to 2005. The results indicated that Australian bank stock returns were not negatively impacted by the announcement of increases in official interest rates. Furthermore, banks apparently experienced net-positive abnormal returns when cash rates are increased, which is consistent with dividend valuation theory that suggests if income effects dominate, then stock returns need not be negatively impacted.

\subsubsection{Inflation Rate and Manufacturing Sector}

This section shows studies done by other researchers on the relationship between inflation rate and the manufacturing sector.

Haslag and Koom (2009) and Boyd and Levine (2001), using cross sectional data and panel information data from 1960 to 2000 studied the effect of inflation on the financial performance of the manufacturing sector, they found out that moderate inflation has a negative impact on the financial development of the manufacturing sector and other sectors in an economy. Both studies and evidence of non-linearity, that is after a particular threshold, 15\% per year in Boyd and Levine (2001) inflation presents only a smaller marginal negative effects on financial development. Dehesa and Druck (2007) used a panel of 120 countries between 1997 and 2004 to report that lower inflation increases the amount of credit in their sample.

Doguwa (2012) re -examined the issue of the existence and the level of inflation threshold in the relationship between inflation rate and the performance of manufacturing industries in Nigeria. Using different approaches that provide appropriate procedures for estimating the threshold level and inference. The results revealed a two threshold point model with $11.2 \%$ and $12.0 \%$ as the appropriate inflation threshold points. These results suggested that the threshold level of inflation above which inflation is detrimental to growth is estimated at $10.5 \%$ to $12 \%$ for Nigeria.

Mwakonemela (2013) examined the impact of inflation on economic growth in Tanzania, using time series data for the period 1990 to 2011. The study adopted the Johansen-cointergration test in analyzing the data. Results revealed that inflation has a negative impact on the manufacturing sector, agricultural sector and on economic growth. In contrast Umaru and Zubairu (2012) assessed the impact of inflation on development and economic growth in Nigeria. The results revealed that inflation possessed a positive impact on economic growth.

This study seeks to determine if there is a positive or a negative relationship between inflation rate and the financial performance of the manufacturing sector in Kenya. The study will use data on inflation rate obtained from World Bank from 1980 to 2016. 
International Journal of Social Science and Economic Research

ISSN: 2455-8834

Volume:06, Issue:06 "June 2021"

\subsubsection{Gross Domestic Product and the Manufacturing sector}

Study conducted by Makori (2015) on the effect of GDP on the financial performance of the manufacturing sector in Kenya using secondary data from the period of 2004 to 2013. Using regression on time series data he found out that there is a positive relationship between GDP and the financial performance of the manufacturing sector.

Kambhampati (2005) study about firms in Turkey analyses profit persistence and its determinants. The study indicates that there is persistence of industries profitability in Turkey however institutional barriers reduce them. The study concluded that GDP has a significant influence on firms' profitability at the country level.

Study conducted by Kormendi and Meguire (2002) using data from 47 countries in the period of 1960 to 2000 found a positive effect of GDP and the financial performance of the manufacturing sector.

According to et.al (2005) during periods of a boom the demand for credit is high as compared to during periods when the economy is experiencing a recession. Ongore and Kusa (2013) argue that during periods of declining GDP growth the demand for credit falls which in turn negatively affect the profitability of a bank. On the other hand a growing economy as expressed by a positive and increasing GDP would lead to an increase in the demand for credit hence leading to growth in profitability.

Oriwo (2012) studied the relationship between macroeconomic variables and manufacturing performance in Kenya. The study found that there exist a significant relationship between macroeconomic variables and the manufacturing performance. This relationship was found to be either positive or negative depending on which variable is being put under consideration. This study recommended that the macroeconomic environment is very important and should closely be monitored to ensure stability.

From the above studies, there exist an empirical gap on the effects of macroeconomic variables on the performance of manufacturing firms, banks and other industries in Kenya. Therefore these variables should be controlled in order to ensure stability in all sectors. Studies conducted in foreign countries may not be applicable in Kenya because their economic environment is not the same as that of Kenya. Equally, effects of inflation rate, interest rate and GDP fluctuation are unique to each industry. While macroeconomic variables affect all industries in the economy, the extent of such effects differ from one industry to another. This research will therefore seek to determine the effects of inflation rate, interest rate and GDP targeting the manufacturing industries in Kenya. 
International Journal of Social Science and Economic Research

ISSN: 2455-8834

Volume:06, Issue:06 "June 2021"

\subsection{Theoretical Review}

\subsubsection{Liquidity Theory}

The theory looks at the interest rate as the token paid for abstinence and inconveniences experienced for having to part with an asset whose liquidity is very high (Phillips, 1991). It is the price that equilibrates the desire to hold wealth in the form of cash with the available quantity of cash, and not a reward of savings. According to Keynes, individuals value money for the transaction of current business and its use as a store of wealth. Interest rate is a function of income, its major role is to help mobilize financial resources and ensure the efficient utilization of resources (Ngugi, 2001). The interest rate measures the rate of return expected by the lenders.

Cowley (2007) interest rate is the price the borrower pay for the use of money borrowed. Excessive interest rate fluctuation can pose significant threats to firm's earnings and capital base changes and increase its operating expenses. Changes in interest rate may also affect the value of assets, liabilities, and the value of future cash flows.

In relevance to the study, liquidity theory explains the role of macroeconomic variables which is to create liquidity in the economy which promotes economic activities and leads to increased manufacturing industries profitability.

\subsubsection{Deflation Theory}

The theory was proposed by Irving Fisher (1933) following the Wall Street crash of 1929 and the ensuring great depression. The essence of the theory was on interactive process whereby falling commodity prices increased the debt burden of borrowers. The modern debt deflation process includes falling asset prices, debt repayment difficulties, a reluctance to lend, a financial crisis, the impact on the banks and the interdependency of the financial system. Recent debt-deflation have been aborted by lender of last resort intervention and government support of the financial system. According to Irving Fisher a fall on inflation rates leads to fall in the level of prices of goods and services, this leads to fall in the net worth of business hence reduced profitability. The reduced profitability hasten bankruptcies which leads the concerns running at a loss to make a reduction in output, in trade and in employment of labor. The cycles cause complicated disturbances in the rates of interest and a fall in the money value. The complicated disturbances described above can summed as both external and internal forces, that is macro and micro factors influencing state of over indebtedness existing between, debtors or creditors or both which can compound to loan defaults.

In relevance to the study, the deflation theory assumes that reduced inflation rates will lead to reduced manufacturing industries sales, reduced profitability and can result to bankruptcy. 


\section{International Journal of Social Science and Economic Research}

ISSN: $2455-8834$

Volume:06, Issue:06 "June 2021"

Authors opposed to this theory argue that inflation rate is the most important macroeconomic variable because it affects all the other variables. Increased rate of inflation result to currency depreciation as explained by purchasing power parity. Due to loss of purchasing power of money and erosion of value of money, economic growth slows down and hence negatively affecting country's GDP growth (Pandey, 2009).

\subsubsection{Classical Growth Theory}

Most economies of the world experience a cyclic fluctuation characterized by period of boom and recession. According to the classical growth theory, due to the technological development, the amount of capital increases and the marginal product of labor rises. GDP per capita rises with high living standards, the population will increase hence providing labor to the manufacturing sectors and other sectors, when the GDP per capita is low the population decreases due to poor living standards and this causes a reduction of laborers in the manufacturing sector and other sectors resulting to a low level of production in those sectors. According to Athanasoglou, Sophocles, Matthaios (2005) during periods of a boom the demand for credit is high as compared to during periods when the economy is experiencing a recession. During periods of declining GDP growth the demand for credit falls which in turn negatively affects the profitability of manufacturing industries because the industries will lack enough money to invest, On the other hand a growing economy as expressed by a positive and increasing GDP would lead to an increase in the demand for credit hence leading to growth in profitability of the industries. Hence economic growth rate has a positive effect on the profitability of manufacturing industries and other industries and firms.

\subsection{Conceptual Framework}

The diagram below shows the framework on macroeconomic variables and effect on the financial performance of manufacturing industries in Kenya. It conceptualizes that the manufacturing sector is dependent on inflation rate, interest rate, and gross domestic product growth rate.

Figure 1 shows the independent and dependent variables. The dependent variable is the financial performance of manufacturing industries which will be measured by value added of the industries which is the net output of the industries after adding up all output and subtracting intermediate inputs. On the other hand, the independent variables includes Inflation which will be measured by Consumer price index, Interest rate measured by the Central Bank treasury bills, and finally Gross domestic product measured by the total market value of goods produced. 


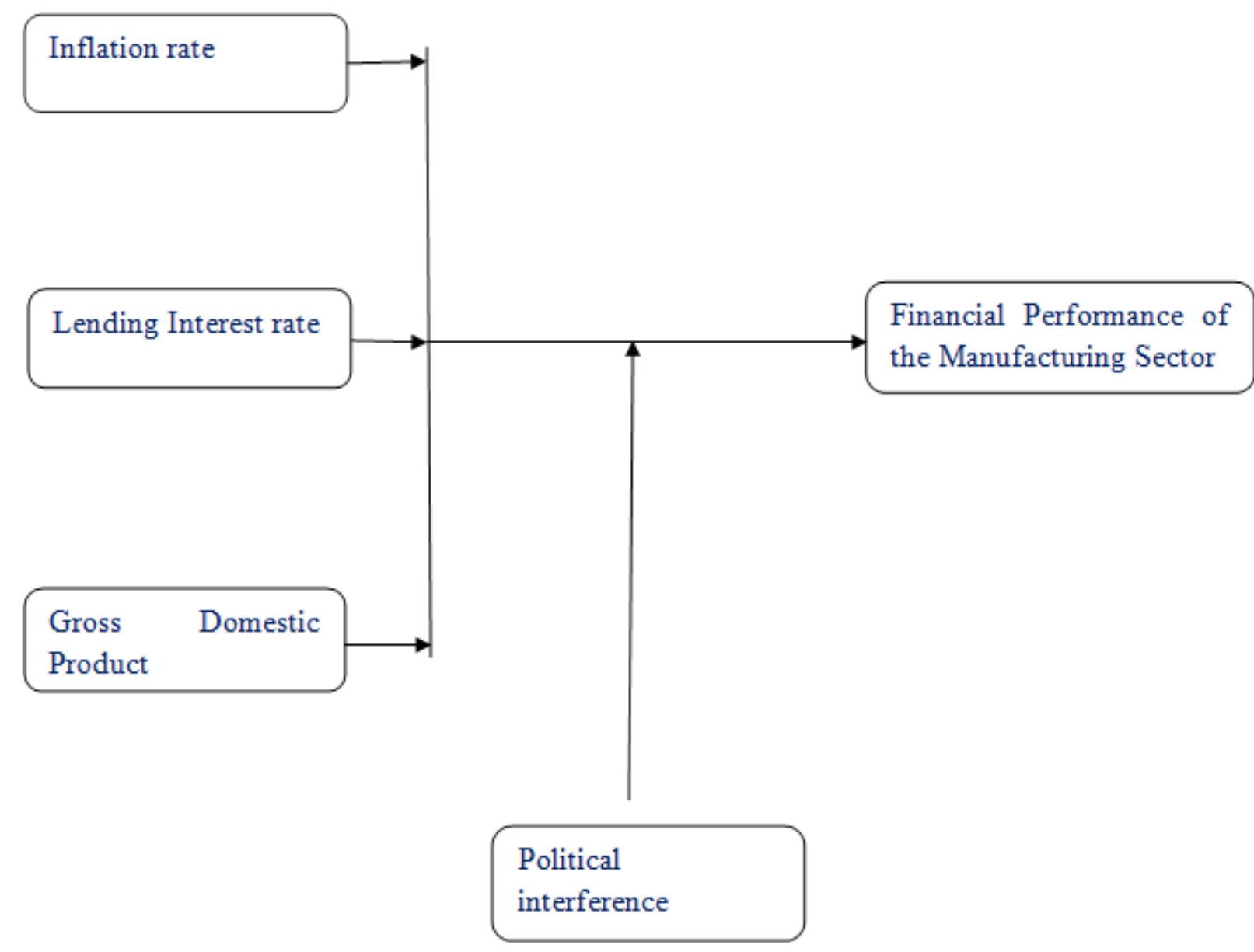

Independent variable

Intervening variable..........Dependent variable

\section{Figure 1: Conceptual framework}

Figure 1 shows the relationship between macroeconomic variable and the financial performance of the manufacturing sector. The financial performance of the manufacturing sector is the dependent variable while inflation rate interest rate and GDP are independent variables. Fluctuation of these variables will affect the financial performance of the sector either positively or negatively.

\subsection{Operationalization of Variables}


International Journal of Social Science and Economic Research

ISSN: 2455-8834

Volume:06, Issue:06 "June 2021"

Table 1: Operationalization of variables

\begin{tabular}{|c|c|c|c|c|}
\hline & VARIABLE & INDICATOR & MEASURE & $\begin{array}{l}\text { EXPECTED } \\
\text { SIGN }\end{array}$ \\
\hline $\begin{array}{l}\text { Dependent } \\
\text { variable }\end{array}$ & $\begin{array}{l}\text { Financial } \\
\text { performance of the } \\
\text { manufacturing } \\
\text { sector }\end{array}$ & Profitability & Value added & \\
\hline \multirow[t]{3}{*}{$\begin{array}{l}\text { Independent } \\
\text { variables }\end{array}$} & Inflation rate & $\begin{array}{l}\text { Annual changes in } \\
\text { prices } \\
\text { commodities }\end{array}$ & $\begin{array}{l}\text { Consumer } \\
\text { price index }\end{array}$ & Negative \\
\hline & Interest rate & $\begin{array}{l}\text { Annual interest rate } \\
\text { fluctuation }\end{array}$ & $\begin{array}{l}\mathrm{CBK} \\
\text { treasury bill } \\
\text { rates }\end{array}$ & Negative \\
\hline & GDP & GDP fluctuation & $\begin{array}{l}\text { Annual GDP } \\
\text { rate }\end{array}$ & Positive \\
\hline
\end{tabular}

Table 1 shows the type of variables, how each of the variables can be measured and the expected sign. The effect of inflation and interest rate on the financial performance of the manufacturing is expected to be negative while that of GDP and the financial performance of the manufacturing sector is expected to be positive.

\section{RESEARCH METHODOLOGY}

\subsection{Introduction}

A literature review carried out to determine the factors affecting the overall performance of the manufacturing industries show that the interest rate, inflation rate and GDP affect the performance of manufacturing industries either positively or negatively. This chapter outlines the research methodology used in carrying out the study. The areas covered in the chapter include, research design, location of the study, target population, sampling and sample size, instrumentation data collection and data analysis.

\subsection{Research Design}

A research design is important since it determines if the research to be carried out is successful. Research design is a conceptual framework within which research is to be conducted. The design stands for advanced planning of data collection methods and analysis procedure keeping in mind the objectives of the research. This study employed causal research design since the study intended to determine whether there is a cause effect relationship between interest rates, 
International Journal of Social Science and Economic Research

ISSN: 2455-8834

Volume:06, Issue:06 "June 2021"

inflation rate GDP and the value added of manufacturing industries, the data collected was used to determine the impact of this macroeconomic variables on the performance of manufacturing industries. This design is an excellent way of finalizing results and proving or disapproving a hypothesis and after statistical analysis of the results a comprehensive answer is reached.

\subsection{Location of the study}

The study was conducted in Kenya because manufacturing industries in Kenya have experienced a slow growth rate and there contribution to the growth of the economy is also minimal due to macroeconomic fluctuation and other factors. The population of the studied consisted of all manufacturing industries in Kenya and also the data of GDP interest rate and inflation rate, but the study focused on those which are listed in the NSE under manufacturing and allied since it would be costly to collect data from all the manufacturing industries located in Kenya. The study was carried out for a period of three months from February to April 2018.

\subsection{Population of the study}

A target population is an entire set of units for which a study data are to be used to make inferences. The target population of this study consisted of all firms listed in NSE under manufacturing firms and allied and all data on inflation rate, interest rate and GDP. There are 10 listed manufacturing firms in the NSE which are classified under manufacturing and allied as at March 2018.

\subsection{Sampling Procedure and Sample Size}

Sampling is a statistical procedure that is concerned with the selection of individual observation from a population especially for the purpose of making predictions based on statistical inferences. Sample size is the number of items to be investigated which are selected from the entire population. The sample size of a study is determined by different factors such as the purpose of the study, data analysis methods and the confidence level. The sample size selected should be unbiased and should represent all the characteristics of the population. Every individual of the population should have equal chances of being selected. The study adopted purposive sampling which allows the researcher to rely on his or her own judgment when choosing members of the population to participate in the study Black (2010). The study used a36 years sample size on three macroeconomic variables that is inflation rate, interest rate and GDP and the value added of the manufacturing sector.

\subsection{Research Instruments}

Instrumentation refers to the tools or means by which investigators attempt to measure validity of or items of interest in the data collection process Salkind (2010). It is related not only to 
International Journal of Social Science and Economic Research

ISSN: 2455-8834

Volume:06, Issue:06 "June 2021"

instrument design, selection, construction and assessment, but also the conditions under which designated instruments are administered. Changes in the calibration of the measuring instrument can lead to based results. The study used a checklist to collect data on inflation rate, interest rate, GDP and the value added of the manufacturing sector, the data was obtained from World Bank.

\subsubsection{Reliability}

Data reliability refers to the consistency of the data measured. The instruments used in data collection and measurement should consistently measure what it is intended to measure. Reliability can be estimated but cannot be measured. One way of estimating reliability is by comparing two tests constructed the same way, from the same content, the study assumed that data used was reliable.

\subsubsection{Data Validity}

Validity is the extent to which an instrument measure what it's expected to measure and performs as it is designed to perform. It is rare for an instrument to be $100 \%$ valid. Validity is generally measured in terms of degrees. Validity can be external or internal, internal validity refers to how the research findings match reality, while external validity refers to the extent to which the research findings can be replicated to other environment. Any research can be affected by different kinds of factors which while extraneous to the concerns of the research can invalidate the findings (Seliger and Shohomy 1989, 1995)

\subsection{Ethical Consideration}

In research maintaining a high level of integrity in handling data collection and analysis procedures is of prime importance (Welman \$ Kruger, 2001). In the study the researcher upheld integrity with utmost honesty in relying data on the variables under study. The researcher also avoided plagiarism in the entire research process by acknowledging the sources of information obtained through in text citations.

\subsection{Data Collection Procedure}

Data collection is the process of gathering and measuring information on variables of interest in a systematic way that enables one to answer stated research questions and test the hypothesis. The study used secondary data of the quoted manufacturing industries from 1980 to 2016. The data used was collected from World Bank. The study used a yearly time series data on inflation rate, interest rate, GDP and the value added of the manufacturing industries.

\subsection{Data Analysis}


Quantitative data analysis technique was used to analyses the data. The data was analyzed by the way of descriptive statistics. The variables in the study were analyzed using Statistical Package for Social Sciences (SPSS) version 20 and STATA software Eviews and Ox Metrix soft wares. Analysis involved estimation of the regression using ordinary least square technique. Statistical inferences were made by analyzing the signs of the coefficients of the variables and also comparing the $\mathrm{p}$-values to the obtained values to check whether they are statistically significant. Hypothesis were constructed whereby the p-values were compared to the critical values. If the $\mathrm{p}$ values were greater than the critical values the null hypothesis was accepted. Signs of the regression were checked to determine the relationship between the dependent and independent variables.

\subsubsection{The Model}

Multiple regression are used when studies involve two or more independent variables. The model for the study was formulated as

$\log \operatorname{Manf}=\beta_{\mathrm{o}}+\beta 1 \log \operatorname{Ir}+\beta 2 \log \operatorname{Inf}+\beta 3 \log G D P+e_{t}$

Where:

$\operatorname{logManf}:$ Logarithm of Value added of the manufacturing industries.

LogIr :Logarithm of Interest rate

LogInf : Logarithm Inflation rate

LogGDP : Logarithm Gross Domestic Product

e : $\quad$ The error term that constitutes the effect of other variables influencing the performance of manufacturing industries apart from interest rate, inflation rate and GDP.

$\boldsymbol{\beta}_{\mathbf{o}}$ :The value of the manufacturing sector independent of the variables under consideration

$\boldsymbol{\beta}_{1}, \boldsymbol{\beta}_{2}, \boldsymbol{\beta}_{3}$ : Coefficients of interest rate, inflation rate and GDP respectively

\subsubsection{Estimation Techniques}

\subsubsection{Error Correction Model}

The error correction model helps in estimating the effects of one variable with another variable both in the Long run and in the short run. The error correction model is obtained after combining 
the error term with the differenced variables. The model is estimated after establishing that there exist co-integration (long run relationship).

\subsubsection{Unit root test}

Unit root test is also known as stationarity test. Mostly time series data is not stationary at level hence if it is used in analysis it gives spurious results (Kennedy, 2003). To overcome the problem of obtaining spurious results the data is tested whether it is stationary. To test this we use Augmented Dickey Fuller Test (ADF). The ADF statistic is compared with the critical values, if the $\mathrm{ADF}$ is less than the critical value then the series is not stationary.

\subsubsection{Co-integration}

Co-integration test is used to test if there exist a long run relationship between the variables. If the parameters under study are integrated with different orders then Johansen Juselius Maximum likelihood method is used to test co-integration, but if they are integrated of same order Engle Granger Two step approach is used to test co-integration.

\subsubsection{Granger Causality Test}

Granger Causality test helps to determine if one variable affects another variable under consideration. Causality can be neutral, unidirectional or bidirectional causality. Unidirectional causality exist when one variable influences the other, bidirectional causality exist when both variables influence each other and neutral causality exist if there is no relationship between the two variables. If the p-value is less than 0.05 significance level then the null hypothesis which states "there is no granger causality" is rejected.

\subsubsection{Diagnostic Test}

These are tests done before estimating the model, they include; autocorrelation, heteroscedasticity and multicollinearity.

\subsubsection{Heteroscedasticity}

This is a problem which occurs if the error term does not have a constant variance. The study used residual plots to test heteroscedasticity. Heteroscedasticity is present when the width of the residuals increases or decreases as the predicted variables increases.

\subsubsection{Multicollinearity}


Multicollinearity occurs when there exist interrelationship between explanatory variables. Multicollinearity is tested using Variance Inflation Factor (VIF). If the VIF is less than 10 then there is no multicollinearity. Multicollinearity is eliminated by transforming the variables.

\subsubsection{Autocorrelation}

This problem occurs when the error term in one time period is related to another error term in another time period. This study used Durbin Watson statistics to detect the presence of autocorrelation. The Durbin Watson statistics values between the range of 2 and 2.5 implies that there is no autocorrelation. Autocorrelation can be eliminated by correct specification of the functional form of the model.

\subsubsection{Lag Order Selection}

Lag order selection or lagging data is determining how many terms relate back to the autoregresion process, determining how the dependent variable at a given time is related to the independent variable at the same period. The best lag to use is chosen as the one with the minimum Arkaike Information Criterion (AIC).

\subsubsection{Normality test}

This is determining whether the data used in the analysis is normal. Normality is tested using skewness statistic or Shapiro Wilk Test for normality. This study used skewness statistic to test normality.

\subsection{Data Analysis Matrix}

Table 2: Data analysis matrix

\begin{tabular}{lllll}
\hline Hypothesis & $\begin{array}{l}\text { Independent } \\
\text { variable }\end{array}$ & $\begin{array}{l}\text { Dependent } \\
\text { variable }\end{array}$ & $\begin{array}{l}\text { Expected } \\
\text { coefficient }\end{array}$ & Test Statistic \\
\hline $\begin{array}{l}\text { Ho1: Inflation rate does not have } \\
\text { significant effect on the }\end{array}$ & $\begin{array}{l}\text { Inflation } \\
\text { rinancial performance of the }\end{array}$ & $\begin{array}{l}\text { Manufacturing } \\
\text { sector }\end{array}$ & negative & t-test \\
manufacturing sector & & & \\
Ho: Interest rate does not have Interest rate & Manufacturing negative & t-test \\
significant effect on the & sector & \\
financial performance of the & & \\
manufacturing sector & Manufacturing negative & t-test \\
$\begin{array}{l}\text { Ho3:GDP does not have a GDP } \\
\text { significant effect on the }\end{array}$ & sector & \\
financial performance of the & & & \\
\hline
\end{tabular}


International Journal of Social Science and Economic Research

ISSN: 2455-8834

Volume:06, Issue:06 "June 2021"

manufacturing sector

\section{DATA ANALYSIS RESULTS AND DISCUSION}

\subsection{Introduction}

This chapter entails presentation of the study's empirical results. It begins with presenting descriptive statistics, normality test, stationary test, diagnostic tests to ensure fulfilment of OLS assumptions and also analysis of the study objectives.

\subsection{Descriptive Statistics}

The table shows the analysis of descriptive data based on mean, standard deviation, minimum and maximum of the study variables during the period of 1980 to 2016

Table 3: Descriptive statistic

\begin{tabular}{|l|l|l|l|l|}
\hline Variable & Mean & $\begin{array}{l}\text { Standard } \\
\text { deviation }\end{array}$ & minimum & maximum \\
\hline manf & 11.87687 & 1.107442 & 9.881747 & 14.45606 \\
\hline infr & 12.27663 & 8.689629 & 1.554328 & 45.97888 \\
\hline Intr & 7.452821 & 6.602149 & -8.009867 & 21.09633 \\
\hline gdp & 3.845637 & 2.324857 & -0.799494 & 8.402277 \\
\hline
\end{tabular}

Table 3 shows that the mean of value added of the manufacturing industries during the period is 11.87687, the standard deviation is 1.107442 , the minimum and the maximum value added during the period is 9.881747 and 14.45606 respectively. The mean of inflation rate during the period is 12.27663 , the standard deviation is 8.689629 , the minimum level of inflation rate during the period is 1.554328 and the maximum level is 45.9788. The minimum level of interest rate during the period is 7.452821 , the standard deviation is 6.602149 , the minimum and the maximum levels of interest rate are -8.009867 and 21.092277 respectively. The table shows that the mean of GDP during that period is 3.845637, the standard deviation is 2.324857 , the minimum is -0.799494 and the maximum level is 8.402277 .

\subsection{Normality Test}

Data that is normally distributed helps in making accurate and reliable conclusions. Normality of the data was tested using skewness goodness of fit test, skewness helps to determine whether the 
International Journal of Social Science and Economic Research

ISSN: 2455-8834

Volume:06, Issue:06 "June 2021"

bell shaped curve is stretched or not stretched to one side. Data is normal and unbiased if the Pvalues are less than 0.05 .

Table 4 shows the skewness and the kurtosis of the data which is used to determine whether the data collected is normal.

Table 4: Normality test

\begin{tabular}{lllll}
\hline Variable & Skewness & Kurtosis & Chi2(2)p & Prob>chi \\
\hline Manf & 0.332 & 0.747 & 1.10 & 0.5761 \\
Infr & 0.000 & 0.001 & 20.28 & 0.0000 \\
Intr & 0.856 & 0.829 & 0.08 & 0.9610 \\
Gdp & 0.516 & 0.111 & 3.19 & 0.2030 \\
\hline
\end{tabular}

From the table 4 we determine if the data is normal by comparing the chi-square probability with $0.055 \%$ significance level. If the $\mathrm{p}$ value (chi-square probability) is less than 0.05 the data is normal but if its more than 0.05 , the data is not normal, that is it contains outliers. From the table above the data on the value added of the manufacturing sector, interest rate and GDP is not normal since the $\mathrm{p}$ values are $0.5761,0.9610$, and 0.2030 respectively which is more than 0.05 , while data on inflation rate is normal. The data is normalized the introducing a log to the data.

\subsection{Stationarity Test}

A time series is said to be stationary if its statistical properties like mean, median and autocorrelation do change over time. A non-stationary time series is rendered stationary through differencing the data. A unit root test is done by use of Augmented Dickey Fuller test to determine if the data is stationary. Stationarity test was done on the value added of the manufacturing sector, interest rates, inflation rates and GDP. The results of the test were as shown below.

\subsubsection{Stationarity Test at Level}

The unit root test was done by Augmented Dickey Fuller test and the results are as below.

Table 5: Stationarity test at level

\begin{tabular}{|ll|l|l|}
\hline Variable & ADF test statistic & $\begin{array}{l}\text { Critical value at 5\% } \\
\text { significance level }\end{array}$ & status \\
\hline lnmanf & -2.241688 & -3.5426 & Not stationary \\
Lninfr & -3.431299 & -3.5426 & Not stationary \\
Lnintr & -2.671522 & -3.5426 & Not stationary \\
lnGDP & -3.711464 & -3.5426 & Stationary \\
\hline
\end{tabular}


International Journal of Social Science and Economic Research

ISSN: 2455-8834

Volume:06, Issue:06 "June 2021"

From the table 5 the ADF test statistic of Ln of the value added of manufacturing sector is 2.241688 which is more than the critical value at $5 \%$ significance level hence the data is not stationary, the ADF test statistic of $\ln$ of inflation rate is -3.431299 this is more than -3.5426 which is the critical value at $5 \%$ significance level hence the data of inflation rate is not stationary. The data on interest is also not stationary because the ADF of the data is -2.671522 which more than the critical value is (-3.5426). The data of GDP is stationary because the ADF test statistic is -3.711464 is less than the critical value of -3.5426 at $5 \%$ significance level. The data that is not stationary was differenced to make it stationary. The results of the data after differencing are as shown below.

\subsubsection{Stationarity Test at First Difference}

The data on value added of the manufacturing sector, interest rate and inflation rate was not stationary, the data was differenced to make it stationary. The results of the stationarity test after differencing were presented as in the table below.

Table 6 Stationarity test at first difference

\begin{tabular}{llll}
\hline Variable & ADF test statistic & $\begin{array}{l}\text { Critical value at 5\% } \\
\text { Level of Significance }\end{array}$ & Status \\
\hline DLNmanf & -3.722487 & -3.5468 & Stationary \\
DLNinfr & -6.383196 & -3.5468 & Stationary \\
DLnintr & -7.743931 & -3.5468 & Stationary \\
\hline
\end{tabular}

Table 6 indicate that the ADF values of the value added of the manufacturing sector, interest rate and inflation rate are $-3.722487,-7.743931$ and -6.383196 respectively, these values are less the critical value at $5 \%$ significance level. This rejects the null hypothesis of non-stationarity implying that the first differenced data of the variables are stationary at $5 \%$ significance level.

\subsection{Correlation Test}

Correlation test is used to determine if there is significant relationship between the dependent and the independent variables. If the correlation value is zero it means there is no relationship, if the value is 1 then there is a perfect relationship, if the correlation value is more than 0.5 then there is a strong relationship and if the value is less than 0.5 then there is a weak relationship. The $\mathrm{p}$ value is used to test the significance of the relationship. A $\mathrm{p}$ value less than 0.5 implies a significant relationship and a $\mathrm{p}$ value of more than 0.5 implies insignificant relationship. 
International Journal of Social Science and Economic Research

ISSN: 2455-8834

Volume:06, Issue:06 "June 2021"

Table 7: Correlation test

\begin{tabular}{lllll}
\hline Variable & Lnmanf & Lninfr & Lnintr & Lngdp \\
\hline Lnmanf & 1.0000 & & & \\
Lninfr & 0.2186 & 1.0000 & & \\
Lnintr & -0.3559 & -0.4640 & 1.0000 & \\
Lngdp & 0.0613 & -0.3216 & 0.0941 & 1.0000 \\
\hline
\end{tabular}

Table 7 shows that there is a weak relationship between Lninfr and Lnmanf, there is also a weak relationship between lnintr, lngdp and Lnmanf because there $\mathrm{p}$ value is less than 0.5.The relationship between the values above is weak because there $\mathrm{p}$ value is less than 0.5 .

\subsection{Diagnostic Tests}

These are tests that are done on the data before the model is estimated. These tests include; autocorrelation, multicollinearity and heteroscedasticity test.

\subsubsection{Autocorrelation Test}

These occurs when the error term in one time period is related to the error term in another time period. It's tested using Durbin Watson test statistic. Autocorrelation leads to biasness and inconsistency of parameter estimates. If the Durbin Watson test statistic is between 0 and 4 there is a weak or no autocorrelation and if the Durbin Watson test statistic is more than 4 , there is a strong negative autocorrelation and if it is less than zero there is a strong positive autocorrelation.Presence of autocorrelation was eliminated by use of correct specification of functional form of the model. The results were presented in table below.

Table 8: Autocorrelation test

\begin{tabular}{lll}
\hline MODEL & DW & STATUS \\
\hline Overall model & 0.663 & No autocorrelation \\
\hline
\end{tabular}

Table 8 shows that there was no autocorrelation since the Durbin Watson test statistic is 0.663 which is between 0 and 4 .

\subsubsection{Multicollinearity}

Multicollinearity occurs when there exist a relationship between the explanatory variables. Multicollinearity is tasted using Variance Inflation Factor (VIF), if the VIF is less than 10 then there is no multicollinearity. Multicollinearity is eliminated by transforming the variables. The results were presented as below. 
International Journal of Social Science and Economic Research

ISSN: 2455-8834

Volume:06, Issue:06 "June 2021"

Table 9: Multicollinearity test

\begin{tabular}{lll}
\hline Variable & VIF & Status \\
\hline Lninfr & 1.50 & No multicollinearity \\
Lnintr & 1.33 & No multicollinearity \\
Lngdp & 1.15 & No multicollinearity \\
\hline
\end{tabular}

\subsubsection{Heteroscedasticity}

Heteroscedasticity test occurs if the error term does not have a constant variance. Heteroscedasticity may also occur when some important variables are omitted from the model. In this study, heteroscedasticity was tested using residual plots. Heteroscedasticity is present if the residuals do not lie along a straight line.

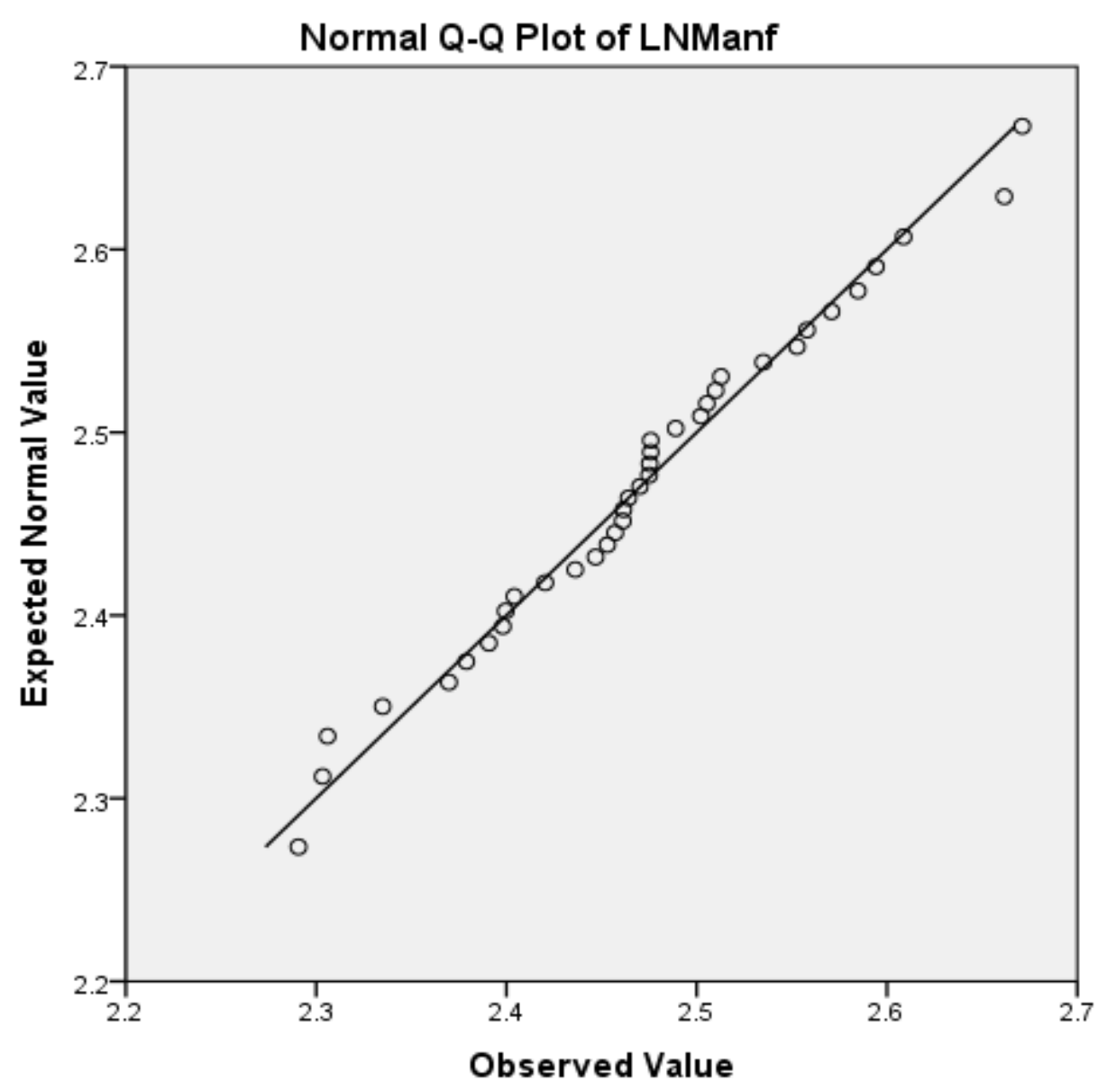

Figure 2:Residual plot of Lnmanf 
Figure 2 indicates that the normal plot of the residuals lies along a straight line. This implies that the variance of the error term of value added of the manufacturing sector is constant. This satisfies the assumption of the classical linear regression model which requires constant variance of the error term. The results therefore indicated that there is no heteroscedasticity in the model.

The heteroscedasticity test in the data of inflation rate was tested by use of visual inspection on residual plots. The plot is a graph of regression standardized residuals against regression standardized predicted variables. This is a graph of regression standardized residuals against regression standardized predicted values. The results were presented in figure 3 .

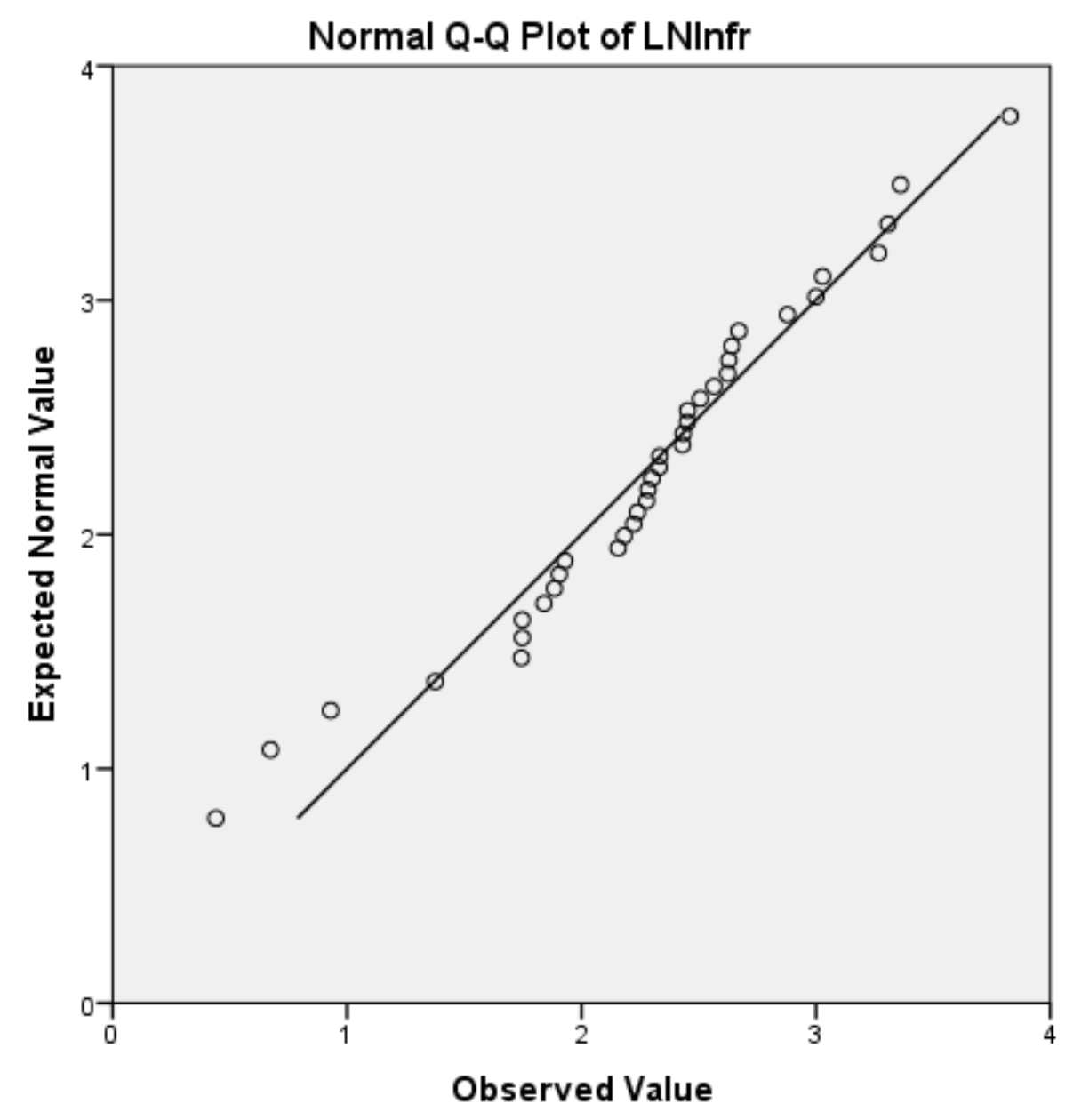

Figure 3: Residual plot of Lninfr 
A visual inspection of the results presented in figure 3 indicated that the residual values lied along a straight line. This implies that the variance of the error term was constant. This satisfied the assumption of the linear regression model of non -heteroscedasticity in the model.

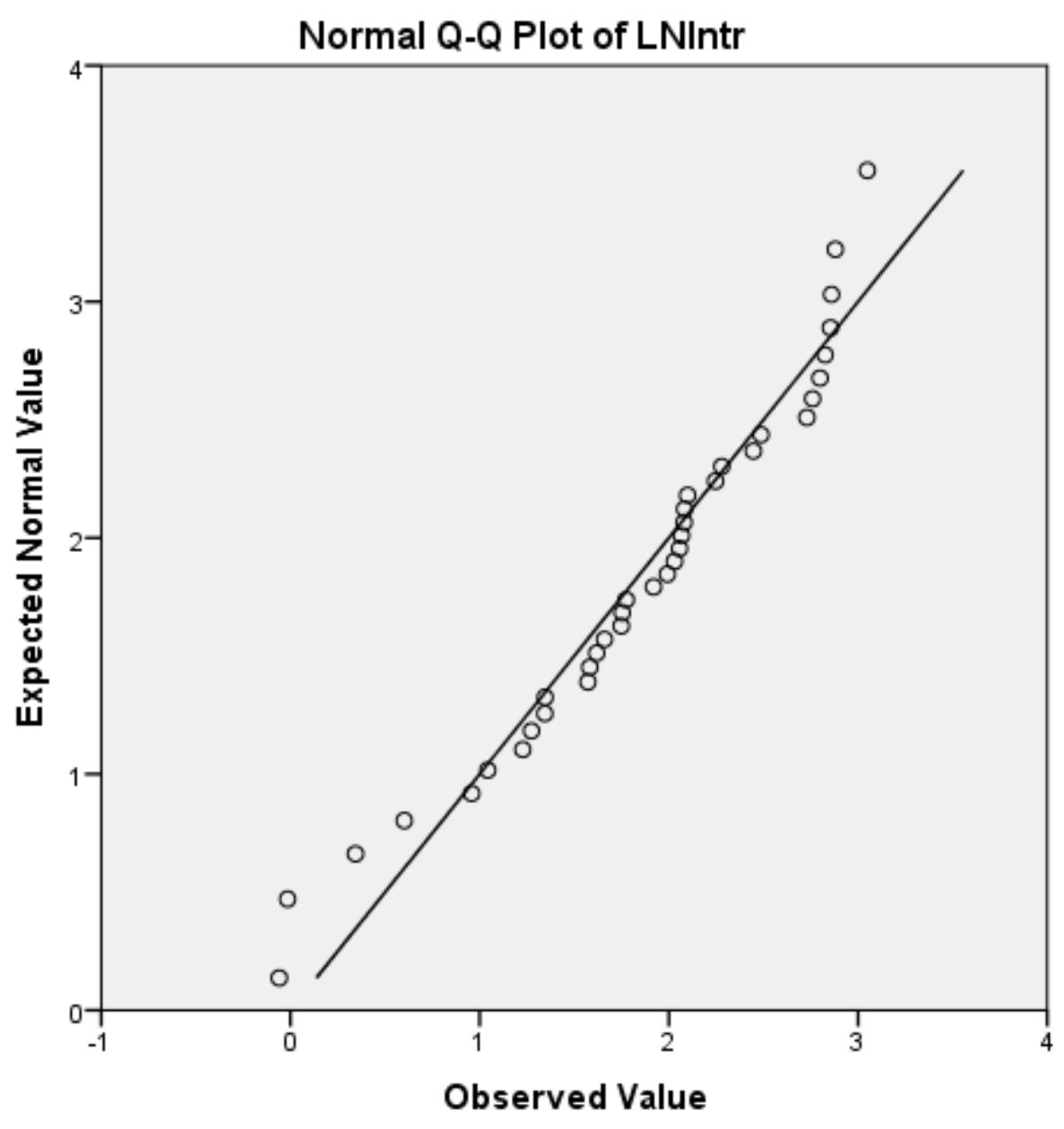

Figure 4: Residual plot of Lnintr

The results from figure 4 showed that the plot of the residual values lied on a straight line. This implied that the variance of the residuals was constant, hence there is no heteroscedasticity. 
International Journal of Social Science and Economic Research

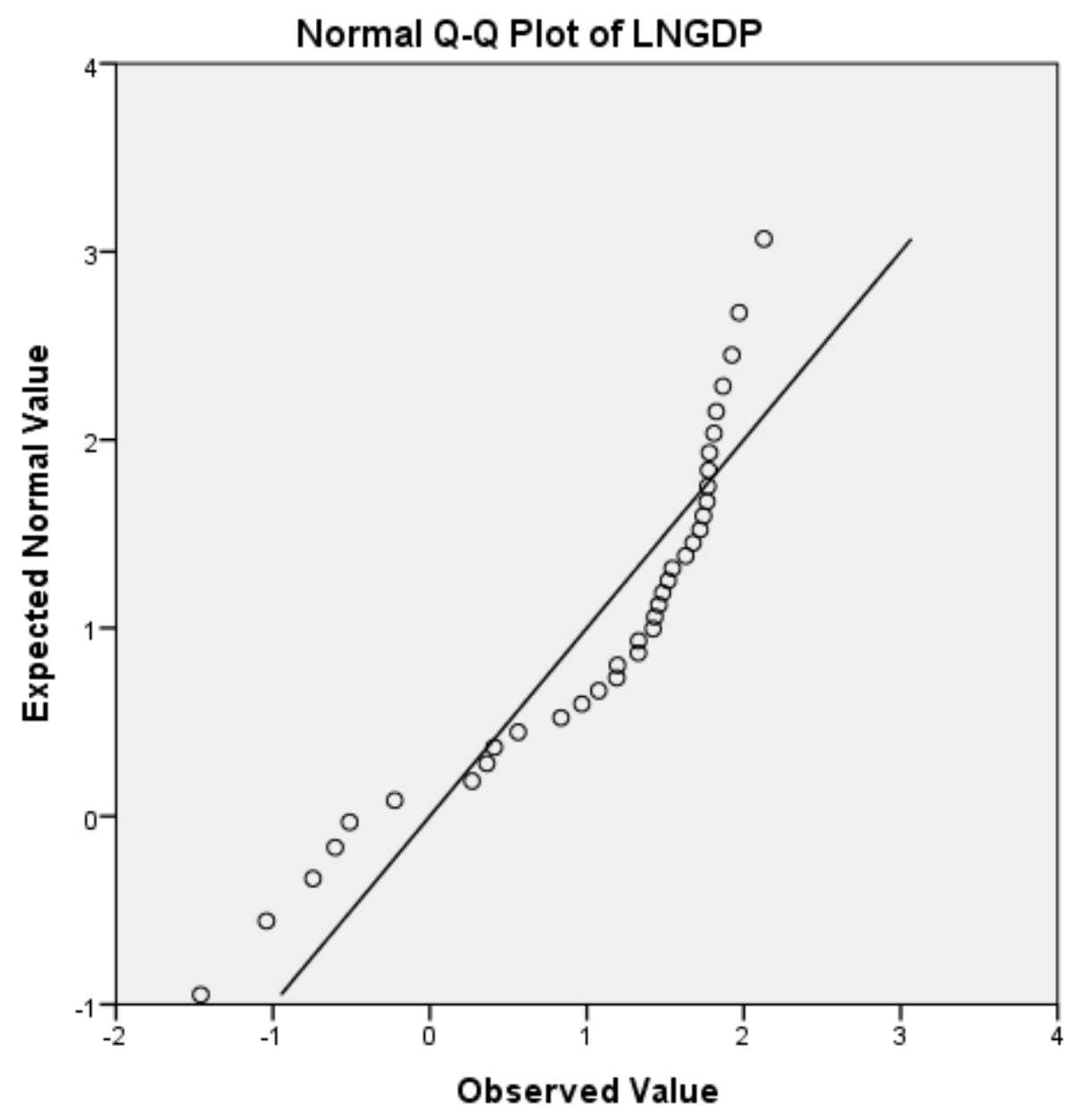

Figure 5:Residual plot if LnGD

The heteroscedasticity test in the data of GDP was tested by use of visual inspection on residual plots. The plot is a graph of regression standardized residuals against regression standardized predicted variables. This is a graph of regression standardized residuals against regression standardized predicted values. The results were presented in figure 5. The results show that there is no heteroscedasticity.

\subsection{Granger Causality Test}

This test is used to determine if one variable affect another variable. The study used Engle Granger Two step approach to test granger causality and the results were as shown below. 
International Journal of Social Science and Economic Research

ISSN: 2455-8834

Volume:06, Issue:06 "June 2021"

Table 10: Granger causality test

\begin{tabular}{lccc}
\hline Null Hypothesis: & Obs & F-Statistic & Probability \\
\hline LNINFR does not Granger Cause LNMANF & 36 & 1.23261 & 0.27492 \\
LNMANF does not Granger Cause LNINFR & & 0.00037 & 0.98471 \\
LNINTR does not Granger Cause LNMANF & \multirow{2}{*}{36} & 0.01436 & 0.90535 \\
LNMANF does not Granger Cause LNINTR & & $4.9 E-05$ & 0.99445 \\
LNGDP does not Granger Cause LNMANF & \multirow{2}{*}{36} & 2.66540 & 0.11206 \\
LNMANF does not Granger Cause LNGDP & & 0.47839 & 0.49399 \\
\hline
\end{tabular}

From the table 10 there exist a bidirectional relationship between the dependent and the independent variables since the p-value for all the variables is less than 0.05 significance level.

\subsection{Co-integration Test}

Co-integration test is used to identify a long run relationship which exist when two or more nonstationary time series possess the same order of integration and a linear combination of these series is stationary. In testing co-integration we first find the residuals of the model and compute the stationarity of the residuals, if the residual are stationary then co-integration exist between the parameters. The results of these study were as shown below.

Table 11: Co-integration test

\begin{tabular}{llll}
\hline Variable & ADF test statistic & P value & Status \\
\hline Residuals & -2.610 & -1.95 & Stationary \\
\hline
\end{tabular}

From the above test the residuals are stationary hence there exist a long run relationship between the parameters.

\subsection{Error Correction Model}

The error correction model helps in estimating the effects of one variable with another variable both in the long run and in the short run. The results of the analysis are s below

Table 12: Short run error correction model

\begin{tabular}{llllll}
\hline variable & coefficient & Std error & t-value & p-value & $\mathrm{R}^{\wedge} 2$ \\
\hline Lnmanf & 0.713395 & 0.1435 & 4.97 & 0.00001 & 0.4687 \\
constant & 0.673941 & 0.3827 & 1.76 & 0.0891 & 0.0997 \\
Lninfr & -0.0290250 & 0.02056 & -1.41 & 0.1690 & 0.0665 \\
Lnintr & -0.000655964 & 0.02201 & -0.0298 & 0.9764 & 0.0000 \\
LnGDP & 0.005544728 & 0.01443 & 0.385 & 0.7035 & 0.0053 \\
\hline
\end{tabular}


International Journal of Social Science and Economic Research

ISSN: 2455-8834

Volume:06, Issue:06 "June 2021"

\begin{tabular}{llllll}
\hline Dummy & -0.00480542 & 0.04871 & -0.0987 & 0.9221 & 0.0004 \\
\hline
\end{tabular}

From the table it was observed that in the short run all the independent variables had no statistical significant effect on the financial performance of the manufacturing sector because their p-value is more than 0.05 . Therefore the null hypothesis that inflation rate, interest rate and GDP have no significant effect on the financial performance of the manufacturing sector were accepted. This implies that in the short run these variables do not affect the financial performance of the manufacturing sector.

Table 13: Long run error correction model

\begin{tabular}{llllll}
\hline Variable & coefficient & Std error & $\mathrm{t}$-value & $\mathrm{p}$-value & $\mathrm{R}^{\wedge} 2$ \\
\hline Lnmanf & 0.707834 & 0.1566 & 4.52 & 0.0001 & 1.0000 \\
Constant & 0.694455 & 0.4416 & 1.54 & 0.0000 & 1.0000 \\
Lninfr & -0.0293817 & 0.02124 & -1.38 & 0.0000 & 1.0000 \\
Lnintr & -0.00020437 & 0.02287 & -0.00894 & 0.0000 & 1.0000 \\
LnGDP & 0.00542191 & 0.01474 & 0.368 & 0.0000 & 1.0000 \\
Dummy & -0.0048054 & 0.04871 & -0.0987 & 0.0000 & 1.0000 \\
Residual & 1.000 & 0.1456 & 3.336 & 0.5436 & 0.0967 \\
\hline $\mathrm{R}^{2}$ & 0.548745 & $\mathrm{~F}(8,27)=$ & 4.104 & 0.003 & \\
& & & & & \\
DW & 1.66 & & & & \\
\hline
\end{tabular}

From the table 13 of the long run error correction model. The p-value for inflation rate, interest rate and GDP is 0.0000 which is less than the significance value of 0.05 therefore these variables have a significant effect on the financial performance of the manufacturing sector. The null hypothesis that states that there is no significant relationship is rejected. The constant was 0.694455 and the coefficient for inflation rate interest rate and GDP was $-0.0293817,-0.0020437$ and 0.00542191 respectively. The coefficient of the dummy variable is negative which means that political instability negatively affects the financial performance of the manufacturing sector. The overall $\mathrm{R}^{2}$ was 0.548745 , which means that $54.8745 \%$ of the variation in the financial performance of the manufacturing sector was explained by the explanatory variables. The Durbin Watson statistic was 1.66 which means that there was no problem of autocorrelation among the error term.

\subsection{Lag Order Selection Criteria}

Time series data in one period may be related with data in another period, to determine how many time one data relate to another we lag the data. The best lag to use in the model is 
International Journal of Social Science and Economic Research

ISSN: 2455-8834

Volume:06, Issue:06 "June 2021"

determined by choosing the minimum Arkaike Information Criteria or the minimum Schwarz Bayesian Information (SBIC). If the AIC and SBIC differ then AIC is used because it is superior.

Table 14: Lag order selection

\begin{tabular}{lll}
\hline Lag & AIC & SBIC \\
\hline 0 & 3.119735 & 3.293888 \\
1 & 2.624502 & 2.844436 \\
2 & 3.122221 & 3.344413 \\
3 & 3.270804 & 3.495268 \\
4 & 3.229336 & 3.456068 \\
\hline
\end{tabular}

From the table 14 the suitable lag length to use is 1 because it has the minimum AIC.

\subsection{Model Estimation}

The model of the study was estimated using a lag of 1 . The model of the study was estimated as below.

$\mathrm{LNMANF}=0.69445 \quad-\quad 0.0293817 \mathrm{DLNINFR}_{\mathrm{t}-} \quad 1^{-} \quad 0.00020437$ DLNINTR $_{\mathrm{t}-1}+$ $0.00542191 D_{L N G D P} \mathrm{t}-1^{-} 0.0048054 \mathrm{D} 1+1.000 \varepsilon_{\mathrm{t}}$

\subsubsection{Effects of Inflation Rate on the Financial Performance of the Manufacturing Sector}

The study sought to establish the relationship between inflation rate and the financial performance of the manufacturing sector. The study found out that there is a negative relationship between inflation rate and the financial performance of the manufacturing sector as shown in the model above. The negative relationship is indicated by the negative sign in the model above. The $\mathrm{p}$-value of the model was 0.0000 which is less than 0.05 . The relationship was significant since the $\mathrm{p}$-value was less than the critical value of 0.05 . The coefficient of inflation rate in the model imply that increase in inflation rate by one unit leads to a decrease in the value added of the manufacturing industries by 0.0293817. The findings imply that increase in inflation rate will lead to a decrease in the financial performance of the manufacturing sector. High inflation rate leads to a decrease in the financial performance of the manufacturing sector by raising the prices of goods and services more so raising the price of assets that will be used in the manufacturing industries, the workers also will demand for high wages in order to pay for the high price of goods and services. Increase in wage expenses will lead to a high cost of production hence leading to low level of production resulting to low level of profit from the produced goods. The results of the study are similar to those ofMwakonemela (2013) who examined the impact of inflation on economic growth in Tanzania using time series data for the period 1990 to 2011. 
International Journal of Social Science and Economic Research

ISSN: 2455-8834

Volume:06, Issue:06 "June 2021"

Results revealed that inflation has a negative impact on the manufacturing sector, agricultural sector and on economic growth.

Haslag and Koom (2009) and Boyd who studied the effect of inflation on the financial performance of the manufacturing sector and found out that moderate inflation has a negative impact on the financial development of the manufacturing sector and other sectors in an economy.

\subsubsection{Effect of Interest Rate on the Financial Performance of the Manufacturing Sector}

The study sought to establish the effect of interest rate on the financial performance of the manufacturing sector. The dependent variable was the financial performance of the manufacturing sector and the dependent variable was interest rate. The model had a coefficient of interest rate of -0.00020437 , the p-value was 0.0000 which is less than 0.05 . Since the $p$ value was less than 0.05 the null hypothesis that there is no significance between interest rate and the financial performance of the manufacturing sector was rejected. The results show that there is a significant relationship between interest rate and the financial performance of the manufacturing sector. From the model above one unit increase in interest rate leads to a decrease in the value added of the manufacturing sector by.0.00020437 Increase in interest rate leads to a decrease in the financial performance of the manufacturing sector because when the rates are high the rate of investment in the manufacturing sector will be low. Low level of investment in the manufacturing sector will lead to few assets for production in the sector hence low level of finances obtained from the sector. These results were similar to those of Okoye (2006) who examined the effect of interest rate on productive activities. Using data on selected manufacturing industries, the study showed evidence of positive effect of interest rate on savings but a negative effect on manufacturing output. The results also were similar to those of Adebiyi and Obasa (2014) who examined the impact of interest rate on the financing of Nigerian manufacturing sub sector using annual data for the period 1970 to 2002 . They found out that interest rates exerts a negative impact on the growth of the subsector.

\subsubsection{Effect of Gross Domestic Product on the Financial Performance of the Manufacturing Sector}

The study sought to establish the effect of GDP on the financial performance of the manufacturing sector. The results of the study showed that there was a positive relationship between GDP and the financial performance of the manufacturing sector. The coefficient of GDP in the model is +0.00542191 this showed a positive relationship between GDP and the financial performance of the manufacturing sector. The $\mathrm{p}$-value was 0.0000 which is less than the critical value of 0.05 , since the p-value is less than the critical value, we reject the null hypothesis that 
International Journal of Social Science and Economic Research

ISSN: 2455-8834

Volume:06, Issue:06 "June 2021"

there is no significant relationship between GDP and the financial performance of the manufacturing sector. The alternative hypothesis there is a significant relationship between GDP and the financial performance of the manufacturing sector is accepted. The positive sign on the coefficient indicated that the relationship between GDP and the financial performance of the manufacturing sector was positive, this implied that a unit change in GDP leads to 0.00542191 increase of the value added of the manufacturing sector. Increase in GDP leads to an increase in the financial performance of the manufacturing sector because when the GDP is high workers of the sector will be paid high wages and this will motivate them to work hard leading to an increase in output of the sector. The high level of output will fetch much profit from the market hence high finances in the sector for expansion. This study results were similar to those conducted by Makori (2015) on the effect of GDP on the financial performance of the manufacturing sector in Kenya using secondary data from the period of 2004 to 2013. Using regression on time series data he found out that there is a positive relationship between GDP and the financial performance of the manufacturing sector. The results also resembled those of Kormendi and Meguire (2002) who studied the effect of GDP on the financial performance of the manufacturing sector and found a positive effect of GDP on the financial performance of the manufacturing sector.

\section{SUMMARY, CONCLUSIONS AND RECOMMENDATIONS}

\subsection{Introduction}

This chapter presents a summary of the findings for the study. It also includes conclusions, recommendations and suggestions for further research.

\subsection{Summary of Findings}

The study aimed at determining the effect of macroeconomic variables on the financial performance of the manufacturing sector in Kenya. To achieve the above, a regression analysis was conducted where the value added of the manufacturing industries was regressed against the macroeconomic variables; inflation rate, interest rate and GDP for the period 1980 to 2016. The data used was obtained from the World Bank.

The study found out that interest rate and inflation rate has a negative effect on the financial performance of the manufacturing sector. The coefficient of inflation rate was -0.029381 , this implies that a unit increase in inflation rate resulted to 0.029381 decrease in the finances of the manufacturing sector. The p-value was 0.000 in the long run this is less than the level of significance which is 0.05 , meaning that inflation rate was statistically significant in determining the financial performance of the manufacturing sector. 


\section{International Journal of Social Science and Economic Research}

ISSN: $2455-8834$

Volume:06, Issue:06 "June 2021"

The relationship between interest rate and the financial performance of the manufacturing sector was also negative, the coefficient of interest rate was -0.00020437 . This means that a unit change in interest rates will affect the financial performance of the sector by 0.00020437 . The p-value was 0.0000 which was less than 0.05 meaning that there was a statistical significant relationship between interest rate and the financial performance of the manufacturing sector.

The relationship between GDP and the financial performance of the manufacturing sector was positive with a coefficient of 0.00542191 . This implies that a unit change in GDP leads to an increase in the profit of the manufacturing sector by 0.00542191 and the p-value was $0.0000<$ 0.05 meaning that there was a statistical significant relationship between GDP and the financial performance of the manufacturing sector.

The $\mathrm{R}^{2}$ was 0.548745 implying that $54.8745 \%$ of the variation profits of the manufacturing sector is explained by inflation rate, interest rate and GDP while the other variation is explained by other variables other than this three macroeconomic variables. The overall significance of the model was tested using the F-statistic and an F statistic of 4.104 was obtained with a p-value of 0.003, this implies that the model was significant and can be relied upon for prediction purposes.

\subsection{Conclusion}

Based on the study findings, the study concludes that macroeconomic variables affect the financial performance of the manufacturing sector in Kenya, but the nature of the effect depend on the specific variable. Interest rates and inflation rates have a significant negative effect on the financial performance of the manufacturing sector in Kenya. This is because interest rate influence the amount of investments in the sector and inflation rate reduces the purchasing power of money consequently reducing the sales. It also increases the cost of production of the manufacturing industries. GDP also has a negative effect on the financial performance of the manufacturing sector in Kenya. GDP growth leads to high manufacturing industries profitability. This is because GDP increases the consumer purchasing power and hence increase in sales of manufactured products leading to increase in industries performance. Macroeconomic variables can account for $54.8745 \%$ of changes in the financial performance of the manufacturing sector. The study concludes that macroeconomic variables should be stabilized in order to reduce the negative impact of these variables on the sector.

\subsection{Recommendations}

Manufacturing sector is one of the major sectors of Kenyan economy, following the findings the following recommendations were suggested:

i. The government should look for measures to ensure that the sector remains profitable. 


\section{International Journal of Social Science and Economic Research}

ii. The CBK should formulate policies to stabilize macroeconomic variables, it should formulate policies to ensure that inflation rate and interest rate are stable.

iii. The government should also come up with measures to ensure that economic growth remains stable and on the rise. This is based on the finding that GDP has a positive effect on the financial performance of the manufacturing sector.

iv. The study recommends that more manufacturing industries should be constructed to create employment and increase economic growth of the nation.

v. The government should ensure that inflation rate and interest rate remains low since they have a negative effect on the financial performance of the sector.

\subsection{Suggestions for Further Studies}

From the findings, the study suggested the following areas for further research

i. Since the study focused on the effect of GDP on the financial performance of the manufacturing sector, further research is recommended on the effect of real GDP on the financial performance of the manufacturing sector.

ii. Further research should be conducted on the effect of macroeconomic variables on the performance of other sectors a part from the manufacturing sector.

iii. The study used only 10 manufacturing industries that are listed in NSE, further research should be done using a large sample.

\section{REFERENCES}

Aburime, U. (2005) Determinants of Firm Profitability: Company-Level Evidence from Nigeria.

Adebiyi, M. A. \& Obasa, B. B. (2004) Institutional framework, interest rate policy and the financing of the Nigerian manufacturing sub-sector.

Adofu, I,Abola, M. \& Audu, S. I. (2010). An assessment of the effects of interest rate deregulation in enhancing agricultural productivity in Nigeria.

Anzeste (2016). Major determinants of the financial performance of the manufacturing sector and the problems facing the sector.

Athanasoglou, Sophocles, Matthaios (2005). Comparison of demand in the economy during period of boom and recession. 


\section{International Journal of Social Science and Economic Research}

ISSN: 2455-8834

Volume:06, Issue:06 "June 2021"

Cowley (2007). Interest rate fluctuation in the economy of Kenya.

Chen, M.H., Kim, W.G., Kim, H.J. (2005). The impact of macroeconomic and nonmacroeconomic forces on hotel stock returns,

Darfor J and Agyapyong (2010). Effects of macro- economic variables on commercial banks

Grossman, P.Z., \& Horvath, J. (2000). The Dynamics of the Hungarian Hyperinflation.

Guerrero, F., \& Parker, E. (2006). Deflation and recession.

Hope, k. (2014). Informal economic activity in Kenya: Benefits and drawbacks.

Hoslog and Koom (2009). Effects of inflation on the financial performance of the manufacturing sector

Kambhampati (2005). Firms in Turkey analyses, profits, persistence and its determinants.

Kenya Economic Survey. (2016). Presented at the Devolution and Planing workshop, institute of economic affairs.

Kinyanjui, M. (2010).Social relations and association in the informal sector in Kenya.

Kormendi and Meguire (2002). Effect of GDP on the financial performance of the manufacturing sector

Kothari C. R. (2004). Research methodology, Methods and techniques. (2nd ed. pp. 140-150).

Loayza, Norman V., Romain Ranciere, Luis Serven, and Jaume Ventura (2007): Macroeconomic Volatility and Welfare in Developing Countries: An Introduction, World Bank Economic Review 21 343-357

Makori (2015). The effect of GDP on the financial performance of the manufacturing sector in Kenya

Menike K. (2006). The relationship between stock returns and inflation: new evidence from wavelet analysis. Journal of Empirical Finance, 435-444.

Mugenda, A. \& Mugenda, O. (2003). Research methods; quantitative and qualitative approaches. Africa Center for Technology (ACTS), Nairobi Kenya.

Mwakonemela (2013). The impact of inflation on economic growth in Tanzania. 


\section{International Journal of Social Science and Economic Research}

ISSN: 2455-8834

Volume:06, Issue:06 "June 2021"

Mohammed (2013). Impacts of macroeconomic variables on the performance of the manufacturing industries in Kenya.

Ngugi, W. (2001). An Empirical Analysis of Interest Rate Spread in Kenya. African Economic Research Consortium, Research Paper 106

Odhiambo (1991). Determinants of the financial performance of the manufacturing sector in Kenya.

Okoye (2006) Effects of interest rates on the productive activities in Ghana.

Ongore, V.O. (2011). The relationship between ownership structure and firm performance

Oriwo (2012). The relationship between macroeconomic variables and manufacturing performance in Kenya.

Osoro and Ogeto (2014) Effects of macroeconomic fluctuations on the financial performance of listed manufacturing firms in Kenya.

Pettinger (2016). Effect of inflation rate fluctuation on industries.

(Pandey, 2009). The influence of the purchasing power and the GDP of a country.

(Phillips, 1991). The liquidity theory.

Salkind (2010). Research instruments, sample selection and data collection, pdf.

(Seliger and Shohomy 1989, 1995). Factors that affect the research findings of a researcher.

(Singh, 1993). Impact of GDP on the performance of the economy.

Torlogh (2013) Impact of high bank lending rates on manufacturing output in Nigeria.

Vong, A, Hoi, S. (2009) Determinants of Bank Profitability in Macro. Faculty of Business.

\section{LIST OF ABBREVIATIONS}
ADF
: Augmented Dickey Fuller Test
DW : Durbin Watson Test Statistic
GDP :Gross Domestic Product
KNBS : Kenya National Bureau of Statistics 
International Journal of Social Science and Economic Research

ISSN: 2455-8834

Volume:06, Issue:06 "June 2021"

NSE : Nairobi Stock Exchange

VECM : Vector Error Correction Model

VIF : : Variance Inflation Factor

WBG :World Bank Group

APPENDICES

APPENDIX 1: DATA COLLECTION CHECK LIST

\begin{tabular}{|l|l|l|l|l|}
\hline YEAR & Value added & Inflation & Interest & GDP \\
\hline 1980 & 12.84154 & 13.85818 & 0.942589 & 5.591976 \\
\hline 1981 & 12.33925 & 11.60305 & 1.410506 & 3.773544 \\
\hline 1982 & 12.20962 & 20.66671 & 2.605412 & 1.506478 \\
\hline 1983 & 11.75312 & 11.39778 & 3.572394 & 1.30905 \\
\hline 1984 & 11.89206 & 10.2841 & 3.83512 & 1.755217 \\
\hline 1985 & 11.71814 & 13.00657 & 5.257538 & 4.300562 \\
\hline 1986 & 11.8912 & 2.534276 & 4.864495 & 7.177555 \\
\hline 1987 & 11.55176 & 8.637673 & 8.15739 & 5.937107 \\
\hline 1988 & 11.88534 & 12.26496 & 8.026232 & 6.203184 \\
\hline 1989 & 11.67149 & 13.78932 & 6.815212 & 4.690349 \\
\hline 1990 & 11.72303 & 17.78181 & 7.332797 & 4.192051 \\
\hline 1991 & 12.04824 & 20.0845 & 5.745513 & 1.438347 \\
\hline 1992 & 10.79349 & 27.33236 & 1.825329 & 0.79949 \\
\hline 1993 & 10.00803 & 45.97888 & 3.413472 & 0.353197 \\
\hline 1994 & 10.69476 & 28.81439 & 16.42811 & 2.632785 \\
\hline 1995 & 9.881747 & 1.554328 & 15.80165 & 4.406217 \\
\hline 1996 & 13.26 & 8.864087 & 5.77659 & 4.146839 \\
\hline 1997 & 12.90975 & 11.36185 & 16.87957 & 0.474902 \\
\hline 1998 & 12.30348 & 6.722437 & 21.09633 & 3.290214 \\
\hline 1999 & 11.42915 & 5.742001 & 17.45405 & 2.305389 \\
\hline 2000 & 11.62369 & 9.980025 & 15.32743 & 0.599695 \\
\hline 2001 & 11.00231 & 5.738598 & 17.8125 & 3.779906 \\
\hline 2002 & 11.06862 & 1.961308 & 17.35814 & 0.54686 \\
\hline 2003 & 10.9223 & 9.815691 & 9.770511 & 2.932476 \\
\hline 2004 & 11.24976 & 11.62404 & 5.045258 & 5.1043 \\
\hline 2005 & 11.82392 & 10.31278 & 7.609988 & 5.906666 \\
\hline 2006 & 14.3201 & 14.45373 & 8.00987 & 6.472494 \\
\hline
\end{tabular}


International Journal of Social Science and Economic Research

ISSN: 2455-8834

Volume:06, Issue:06 "June 2021"

\begin{tabular}{|l|l|l|l|l|}
\hline 2007 & 14.45606 & 9.75888 & 4.819091 & 6.85073 \\
\hline 2008 & 13.58138 & 26.23982 & 0.985 & 0.232283 \\
\hline 2009 & 13.38647 & 9.234126 & 2.837078 & 3.30694 \\
\hline 2010 & 12.61631 & 3.961389 & 12.0259 & 8.402277 \\
\hline 2011 & 13.0769 & 14.02155 & 3.840676 & 6.111613 \\
\hline 2012 & 12.24803 & 9.378396 & 9.456607 & 4.5632 \\
\hline 2013 & 11.88125 & 5.718274 & 11.54773 & 5.879764 \\
\hline 2014 & 11.01886 & 6.877498 & 7.815634 & 5.35184 \\
\hline 2015 & 10.32886 & 6.582411 & 5.896232 & 5.713383 \\
\hline 2016 & 10.03421 & 6.297548 & 7.899352 & 5.848665 \\
\hline
\end{tabular}

